\title{
Cyclical Changes of Space: The phenomena of space changes in historic-religious Kampung Luar Batang, Jakarta, Indonesia
}

\author{
Popi Puspitasari ${ }^{1}$, Achmad Djunaedi ${ }^{2}$, \\ Sudaryono, Heddy Shri Ahimsa Putra ${ }^{3}$ \\ ${ }^{1}$ Architectural Engineering and Planning Department, \\ Gadjah Mada University, Yogyakarta, Indonesia. \\ ${ }^{2}$ Promotor, ${ }^{3}$ Co-Promotor \\ Popi_Puspitasari@yahoo.co.uk
}

\begin{abstract}
Kampung Luar Batang is a modern-traditional urban settlement occupied by a heterogeneous community with hybrid culture, at the proximity of an urban pilgrimage center - a maqom (sacred tomb). By employing phenomenological research methodology, this study has been able to understand how the religious, traditional and economic activities Kampung have simultaneously generated the phenomenon of changes in the articulation of space in cyclical patterns (annually, weekly, anddaily). Social exchange based on religious-tradition has generated fluid, elastic, and changeable spatial characteristics. This paper is intended to describe the underlying reasons of these phenomena and to generate a model for these interesting cyclical changes of space..
\end{abstract}

Keywords: Pilgrimage, Cyclical changes of space, Historical-Religious Urban Kampung

eISSN 2514-751X @ 2018. The Authors. Published for AMER ABRA cE-Bs by e-International Publishing House, Ltd., UK. This is an open-access article under the CC BY-NC-ND license (http://creativecommons.org/licenses/bync-nd/4.0/). Peer-review under responsibility of AMER (Association of Malaysian Environment-Behaviour Researchers), ABRA (Association of Behavioural Researchers on Asians) and $c E-B s$ (Centre for EnvironmentBehaviour Studies), Faculty of Architecture, Planning \& Surveying, Universiti Teknologi MARA, Malaysia.

DOI: https://doi.org/10.21834/aje-bs.v3i6.237 


\subsection{Introduction}

The toponymic of Kampung Luar Batang is connected to historical and mythical factors. Historically Kampung Luar Batang was formed during the rule of VOC (Vereenigde OostIndische Compagnie or the Dutch East India Company) which established its capital at the port city of Batavia(the old city of Jakarta). VOC played a major role in the formation of Kampung Luar Batang. Around the year 1730, the VOC reclaimed the northern coast of the city of Batavia westward of Sunda Kelapa Harbor. The reclaimed land was used for residential area to settle the Javanese laborers employed by the VOC to lift a pile of mud from the Ciliwung River estuary which was increasingly becoming shallow. Marrillees (2000) and Shahab (2004) explained that the ships were inspected before entering the harbor and the sailors had to pay taxes at the custom, and only then the officials would allow them entering into the Ciliwung River estuary and to enter thetown behind the city walls. Reclaimed land at the northern part of the town would then be called 'Kampung Luar Batang' because the Kampung was located outside the Boom or the harbor (Buiten de Boom). To control the native population movements, VOC subdivided settlements outside the city walls into a number of Kampungs based on ethnicity. Kampung Luar Batang on C.A von Luepken's map in year of 1780 is identified as Java Quartier. (Heuken, 1997: Hakim,1989:51)

Another version of the origin of Kampung Luar Batang name came from the local myth about Al Habib Husein bin Abubakar Al-Aydrus who came to Batavia in 1736. The Dutch Governor granted land to Al-Habib Husein to be used as a residence and for worship. According to a record, Al-Habib Husein died on June 27, 1756 at the age of approximately 40 years old and was buried in Luar Batang. According to the popular belief, Al-Habib's body was carried in a Kurung Batang (coffin) to a graveyard at Tanah Abang (an area outside the city wall further south) as planned, but on reaching the location, Al-Habib's body was no longer there and it had returned to his home. The locals then called it Luar Batang or out of the cofßn. The two tombs which received many visitors are for Al-Habib Husein bin Abubakar Al-Aydrus and for one of his followers, a Chinese called Nek Bok Seng who died earlier than him. (Azyumardi in Heuken 2003:52-53; Sayid Abdullah bin Abubakar Alaydrus, 1998: Heuken, 2003: 53-54).

Its strategic position in relation to the intensive urban and pilgrimage centres became the reasons for the increase of density of dwelling activities and the intensity of public space utilization. Additional activities generated by the pilgrimage to the maqom (sacred tomb) of Al Habib Husein [such as Pasar Malam Jum'at (Friday eve market on Thursday night), bazaar, street hawking, air barokah (holy water) trading, kembang payung (flowers and artificial umbrella) and kemenyan (incense) selling, etc.] has been dominating the public space around the mosque in cyclical manner. This time-cycle is based on non-verbal commitment, scenario-based commitment, and Islamic calendar. As a result a dynamic spatial form is formed and not cointained within the physical solids, but by abstract, fluid, and elastic morph. 


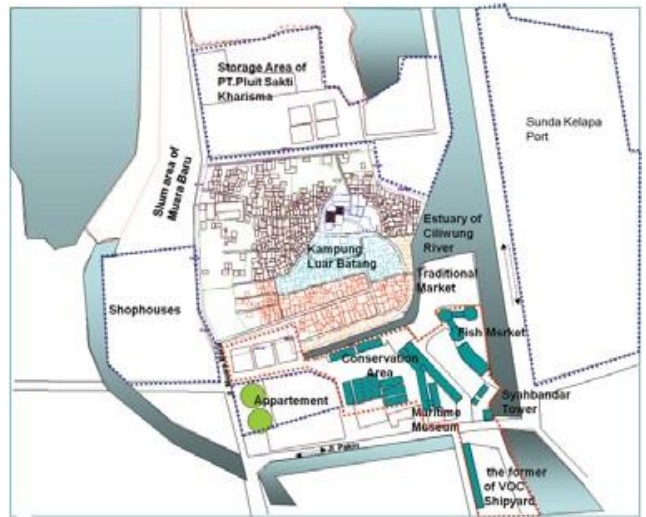

Figure 1: The functions around Kampung Luar Batang (Source: Reconstruction, Google Earth, 2008)

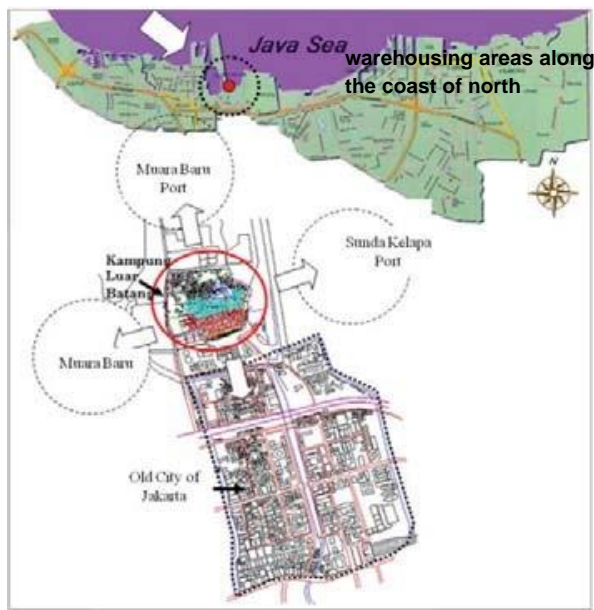

Figure 2: Location of Kampung Luar Batang and its Surrounding (Source: Reconstruction by Author based on Google Earth, 2008)

\subsection{Literature Review}

Space' has two important functions: as the container of social activities, and as the actualization of spiritual content (mental thing, or mental space). Mental space transforms a 'space' from a 'container' into a 'place' (in Latin: loci), therefore the 'container' possesses values, symbols, and spirits which goes beyond the geometrical-physical envelope ('room'). In other word, 'space' has both tangible dimension and intangible dimension, or is able to be 
experienced physically and non-physically. Deformation, transformation, and typology of 'room' are therefore interpreted as the articulation of the community's social interaction.(Van deVen, 1991:XVII, Mangunwijaya, 2009:152, Dear \& Wolch in Carmona, 2003:106)

Social space is a social product, constructed through space, constrained by space and mediated by space (Lefebvre, 1984). In this case 'space' is symbolically constructed by a system of values, moral norms and ethics that subsequently shape the identity of its inhabitants. Conceptually, the totality of architectural space includes: physical control, functional frame, social milleu and cultural symbolical (Cohen, 1985:9; Schulz, 1963, 1980).

Historical-religious urban Kampung is a locus, of which physically, functionally, socially, and cultural-symbolically, has a mixture of 'Kampung- like' characters (dense- low-rise settlement, diverse, unplanned, informal, communal, traditional, etc.) and 'urban-like' characters (dense- high-rise settlement, monotonous, planned, formal, individualistic, modern, etc.). The historicity and religiosity are the two main important factors to sustain its existence, because of its economic independence. (Sihombing, 2004 quoted Radovic 1994: 166 and Jacobs, 1961: 155; Juwono, 2005; Haryadi, 2010). Tradition and religiosity generate a certain social exchange system, which become the local-, traditional-, or primitive- economic generator. Mausse (1961) and Belshaw (1981) proposed a concept that primitive exchange system is magical exchange conducted by the giver and the receiver through a certain ritual with the objective of getting all the goodness (such as wealth, power, good life, peace, fellowship, safety, convenience). It has the power to control everyday life, and became the basic consideration in determining social relations, economic and political activities, religious rituals and beliefs, and other factors. Space (especially public space) becomes commercial commodity because of the activities generated by tradition. Religiosity values are affecting the exchange of spatial values to become obligatory-voluntary exchange. Public space is manifested as Pseudo Public Space which has flexible and conditional characters (according to Carmona, 2003 dan Varley, 1987).

\subsection{Methodology}

In this research the rules of Constitutive Phenomenology of Edmund Husserl is employed to uncover the intangible aspects behind the tangible objects. The data and information are collected through observations and interviews with a number of informants purposively without involving the researcher's subjective views. Moreover, similar information units, which spread over a number of notes, are classified into several categories of phenomena. The explained phenomena below were conceptualized as a form of abstraction of the concepts that emerge from the constellation of each category. Logically the accuracy of knowledge acquired through phenomenological research method depends on the meaning given to match what is seen, thought, and experienced by the informants. Therefore descriptive explanation and reflective action are essential in revealing the truth. (Embree, 1997:9-11,205; Partridge, 2009:416; Kuswarno, 2009: 29-32, 47-48; Haryadi, 2010:22-23; Norberg-Schulz, 1963) 


\subsection{Results and Discussions}

\subsection{The uniqueness of Kampung Luar Batang as a 'magnet'}

Geographically, Kampung Luar Batang has access from both land and sea, and relatively at close distance to the centers of urban economic activities (such as shopping malls in Mangga Dua, Glodok, Grogol, Muara Baru; warehouses in Tanjung Priok Port and along the northern coast of Jakarta, the fish market, and the wholesale centers in Pasar Senin and Tanah Abang). During the VOC period, Kampung Luar Batang was the frontage of the city of Batavia, where various ethnic groups from different islands and countries stopped over, met, and settled down. Kampung Luar Batang is now considered as the oldest historical urban Kampung because of this historical background.

In its course of history (around 1736), Kampung Luar Batang became the landing place of an Islamic missionary, Al Habib Husein bin Abubakar bin Al Aydrus. He passed away in 1756 and his maqom was sited in the old mosque of Luar Batang. Maqom has different meaning with the term of makam. Maqom is designated for somebodywhose knowledge on Islamic faith is high, or for someone who is considered as a close relative of the Prophet Muhammad, while makam is a tomb (source: Mr. Hamid, the native people of RW-3,2008). Pilgrimage to the Al Habib Husein's sacred maqom is considered as a mandatory precedence over all other shrines in greater Jakarta region. It is because, genealogically, he is considered as the oldest guardian and as a closely related to Prophet Muhammad. Currently this pilgrimage activity is significantly contributing to the intensity of commercial activities in open public space around the old mosque. Migrant traders, local inhabitants, and the former inhabitants, are complimenting and taking care of each other, and based this attitude on the realization of proper religious-traditional values in commercializing the public space. Everyone has its own ways to manipulate the public space, according to perceived appropriateness in relation to residency, kinship, friendship, or other status.

\subsection{Cyclical Changes of Spaces, Events and Time}

The pilgrimage activity generates impact to the other activities which appear sporadically. Pilgrimage activity is perceived as an opportunity to develop commercial activities, and moreover is considered as tradition. Space and time of each activity has a particular characteristic.

The hourly penadong activities. Penadong is the local term for beggar. Generally the beggars are the local children. Their activity space is on the mosque yard or following the pilgrims' routes as far as they can reach on foot even if it goes beyond the maqom mosque complex. They will not stop following the pilgrims until the pilgrims giving the alms to those who are older than 7 years old. Penadongs who are younger than 7 years old (pre-school age) operate in the morning and in the afternoon, whilst those who have gone to school operate after 1 PM until 7 PM. On the Islamic celebration days, the pilgrims often do saweran (throwing coins as thanksgiving for the blessings that they have received) or to distribute money arranged by mosque officials at the open space in front of the mosque. Saweran is an opportunity for the beggars to get more pocket money. The begging activity is reaching its peak from the afternoon until evening, also during holidays, Sundays, Friday eves, Islamic 
holidays (such as Haul-the commemoration of the death of Al Habib Husein - and the days before the fasting month of Ramadhan). Although the begging activity is concentrated on the mosque yard, but the changes in the movement and spatial capacities of Penadong are determined by the age, time, and the distance of the pilgrims' route. Thus the increment or changes of intensity in penadong's space is related to the time cycle outside the daily school schedule, the time cycles on Sunday, public holidays, Islamic celebrations, and Haul calendar.

4.3 The daily trading of kembang payung, kemenyan and air barokah. On the way to the maqom mosque, the pilgrims are met by the kembang payung sellers. They offerapacket of flowers and a small artificial umbrella by saying that this is a prerequisite for requesting prayer. Other prerequisite objects, according to the sellers, are kemenyan (incense) and air barokah (holy water). The sellers created a certain ritual route to direct the pilgrims to the room for requesting prayer. For instance, after buying the kembang payung, the kemenyan seller will lead the pilgrim to the kuncen's (caretaker) room (a Habib related to the late Al Habib Husein b. Abubakarb. Al Aydrus), to ask his favor to haste the fulfillment of the requested prayer. Then they will be directed to the place to burn the incense. It is assumed that the pilgrim's prayer has been sent through the smoke of the burned incense. Prior to enter the payer room, the pilgrim is required to drink half cup of the air barokah. After doing this the pilgrim will meet the kuncen (caretaker) and will be assisted to offer the prayer. This ritual procession does not based on fixed or standard rule, but according to observation, is created by the economic actors for them to reap material benefits. Requestfor prayer ritual is the source of daily income for local inhabitants and commuters (group of people who used to live there and presently live outside the Kampung) from around 10AM until 5PM. Space where the ritual procession takes place is formed following imaginary route of kembang payung, kemenyan and air barokah sellers (from the entrance of the mosque, to the room of the caretaker of the alms box, to the room for burning incense, up to the room for prayer request). This imaginary ritual procession space is intensively formed every Friday eve weekly, also on every Islamic holidays and Haul day annually.

The weekly Pasar Malam Jum'at. The peak of noisy trading activity occurs on every Friday eve or Tawassul night. Friday eve market is formed by a number of street hawkers around the mosque on the front yard of the local inhabitants' houses. Basically the market activity follows the dzikir akbar (big prayer) for the late Al Habib Husein (tawassul). This takes place inside the maqom mosque on Friday eve from 4PM till Friday morning 5AM. The merchants who come there are regular migrants or cyclical traders for this particular event. Building elements, such as fences, stairs and roofs which are located alongside the public roads, have been given additional functions as stalls. It becomes the place to display merchandise. Thedrains covered with plywood are used to put the merchandise table, andbalconies between homes are used for mooring ropes to hung tentsto shelter the road. The covered road is used for buying and selling activities. To occupy a street lot, they have to pay service money and electricity fee to the environmental control officers from RW-3 (RW is an administrative area consists of several neighborhood units) since the mosque is located within the RW-3 area. Those who occupy a plot of space on the porch of someone's house (along the road) would pay appropriate compensation to the owner of the house for cleaning 
based on mutual agreement. The local traders who use the public road in front of her housedo not obliged to pay any compensation. RW administrator assumes that the localsunderstood the ethics and responsibilities for not causing any problems or creating disputes.

Since tawassul is a regular activity, therefore the transformation of the street space into Friday eve marketatleasthappens for 4 timesamonth or 48 times in a year. Friday eve market has been regarded as adat (tradition) by the locals; therefore this high intensity activity is not regarded as annoying, but as respecting the adat. Private space which is transformed into public space, or the pseudo public space, is regarded as social-commercial facility based on religious-tradition, and therefore no definite nominal value can be set for the usage of the space.

The annual Bazaar. Bazaar is the local terminology for trading activities such as temporary market along the road around the maqom mosque, which happens every two days celebration of the Maulid Nabi Muhammad, and every Haul day annually according to Islamic (Hijriah) calendar. Bazaar is held from 9.00 AM until the completion of the event. Bazaar occupies the same space as pasar malam Jum'at, which is located on the streets around the maqom mosque. The only difference is the on the number of the traders which is larger, and the nominal rental fee for the usage of the plot. The Birthday of the Prophet's day is celebrated by the men and women on different days. On the birthday celebration by the women, the area that is used as a streetmarket becomes more extensive, because women like to shop more than men. The difference in traders' number and trading location will determine the rental price of the bazaar lot. The higher the number of the traders and the closer the location to the mosque entrance, the more expensive the rent of the plot is. Therefore, the rules become more stringent. On both sides of the road, boundary lines of the lots are marked clearly and given numbers. The merchants can occupy more than one lot and the numbers of lots can be adjusted to the demands according to the numbers of traders. This management of space and time is based on non-verbal negotiations, set by them on the basis of habit or tradition, which in turn promotes closer and more intimate relationship among them. The intensity of usage of the public street space by the itinerant migrant traders reaches its peak three times in a year, in addition to the annual 48 times of Friday eve marketdays.

\subsection{Model of Cyclical Changes of Spaces}

Commercial activities generated by the ritual of prayer request and pilgrimage activities, stimulates the existence of imaginary space. The dynamic of the imaginary space can be described as series of repetitive and constant movement points of the groups of actors, manifested in an amoeboid space which is plastic, flowing, natural, and flexible. The cycle of change of the imaginary space in the case of maqom mosque is determined by the pilgrimage activities which trigger the commercial activities. The intensity and repetitiveness of the actualization of the imaginary space follows the Friday eve calendar, Haul calendar, Islamic calendar, and public holiday's calendar.

Change in the form of imaginary space is also influenced by the formal regulation, including the physical intervention, which forces the change in the pilgrims' flow. Pilgrim is 
the main actor which generating the economic activities, for example the position and the flow direction of the bazaar and the Friday eve market follow the flow of the pilgrims from the starting point onward. The plot nearest to the mosque's gate has higher price, because it is located at the area most intensely passed by the pilgrims and therefore has bigger opportunity to get buyers.

The research indicates that tangible physical form does not determine the form of the imaginary space. Something intangible, such as believe to the religious ritual tradition mechanism, either dogmatic or as strategic scenario with economic motifs, in reality may generate imaginary space which flows in between physical elements or even passes through thephysical boundaries, as a transcendence or metaphysical space.

Cyclical space changes in the context of ritual pilgrimage phenomena and its supporting activities in Kampung Luar Batang can be modeled as a time cycle. The time cycle is activated by pedadong's and supporting traders' calendar following the prayer request ritual, also Friday eve, Haul, and Islamic (Hijriah) lunar calendars. Each calendar invokes specific simultaneous or cyclical changes into space. Based on these time cycles, the existence of the imaginary space can be calculated and reflected in terms of hour, week, or year. Moreover the cyclical changes of space in a pilgrimage location can be associated to the other pilgrimage locations, based on the Wali (guardian) gynecological concept. Therefore the cyclical changes of space are able to penetrate the boundaries of Kampung, city, region, and even country.

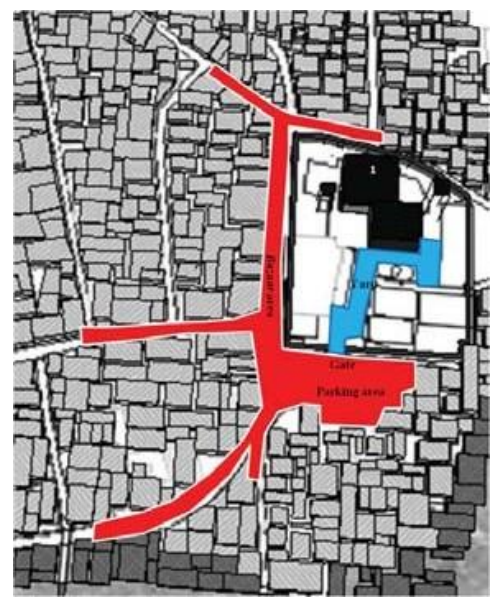

(a)

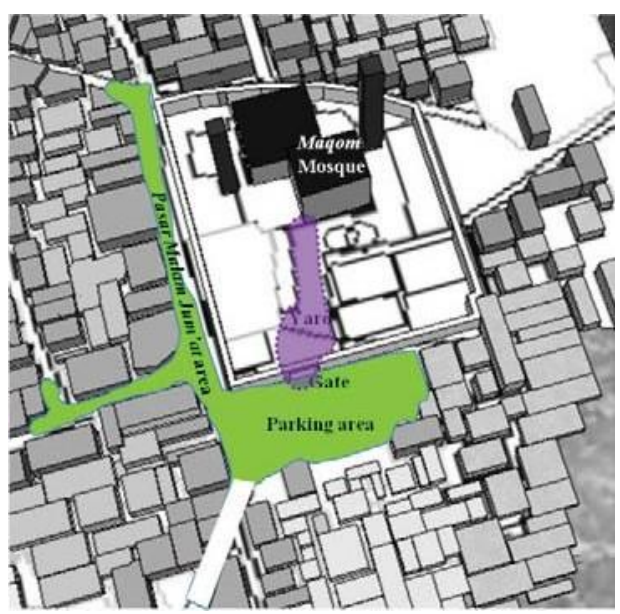

(b) 


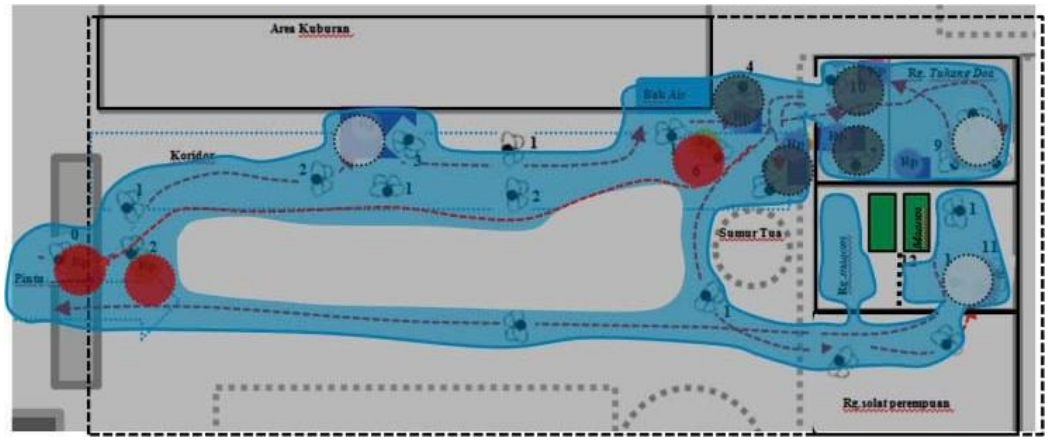

(c)

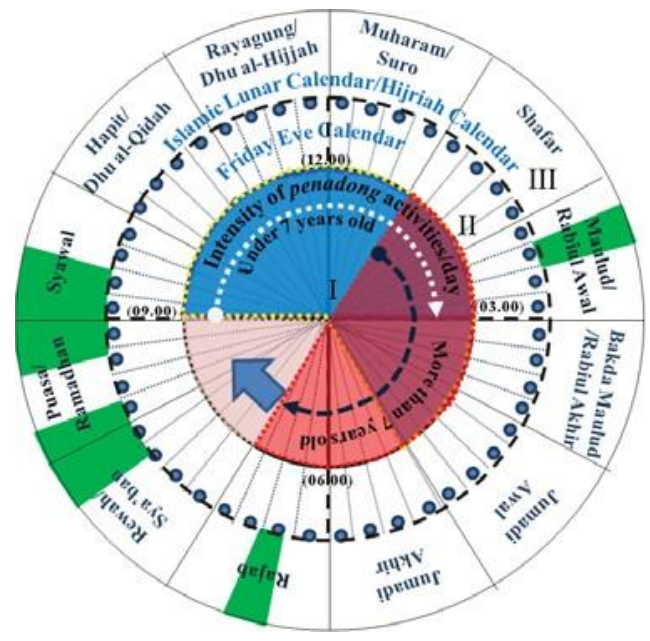

(d)

Figure 3: Cyclical Changes of Space in Kampung Luar Batang: Birthday Celebration of the Prophet

Muhammad's Bazaar Space (a); Pasar Malam Jum'at space (b); requesting prayer space (c); cyclical changes of space model (d) : cyclical time of penadong

(A), cyclical of pasar malam Jum'at calendar (B), cyclical of Haul calendar of Habibs in Jakarta Bogor-Tangerang region (C), Hijriah calendar (D).

(Source: Observation and experience)

\subsection{Conclusion}

The existence of cyclical changes of space in the historical-religious Kampung appears 
because of several factors: (1) preservation of tradition in parallel to the harmonious social relations based on religion, (2) non- verbal commitment based on religious, humanism, and solidarity values, (3) openness towards migrants complemented by flexible and conditional control mechanism to maintain order.

Cyclical changes of space has several characteristics: (1) following time cycle of events, which according to tradition should be preserved and considered as permanent, (2) supported by non-verbal commitments which causes the existence of flowing, natural, and organic imaginary space, (3) not fully bounded by strict formal regulations, (4) appears in the community which opens towards changes in local values, but realizes the existence of common agreement among members of the community to preserve the existence of place.The tradition of cyclical time generates (1) cyclical changes of space, (2) increment of commercial-traditional activities, (3) increment of the usage and commercial value of public space, and (4) increment of place existence as magnet for migrants to come.

What has been presented in this article is part of the overall research results obtained by the researcher. Thus the presented models above are part of a complete set of models of a number of phenomena that occur in the Kampung Luar Batang. It should be realized that the model may need to be changed if a number of significant changes happened to the existing condition. The model is based on a local case study that needs to be compared against other similar cases in order to ultimately obtain a general model. However, originality of data and information is ensured even if its nature subjective. Cross check information to a number of local people is a way to strengthen the validity of research results. As a reflection towards Tourism study, this case would be able to shed light into a form of Religious Tourism. From methodological perspective, it has demonstrated the ability of Phenomenology as a research methodology in revealing the intangible aspects of the tangible objects in the context of historic-religious urban settlement.

\section{Acknowledgement}

I would like to thank the mentors who have provided guidance for preparing the paper substances. The highest appreciation goes to the local informants, the members of mutawali (representative of Habib's family), themosque office staffs, the street hawkers, the kembang payung sellers, kiosk owners, and incense sellers, who had openlyreceived me when the field research was conducted.

\section{References}

Abdullah, Sayid. (1998), Sepintas Riwayat Shahibul qutab Alhabib Husein bin Abubakar Alaydrus, Jakarta: Mutawali Luar Batang.

Belshaw, Cyril S. (1981), TukarMenukar Tradisional dan PasarModern, Jakarta: PT.Gramedia.

Carmona, Matthew; Heath, Tim; OC, Taner; Tiesdell, Steve. (2003), Public Places Urban Spaces, Oxford: Architectural Press. 
Cohen, A.P.; Hamilton, Peter (ed). (1985), The Symbolic Construction of Community, New York: Ellis Horwood Ltd. Embree, Lester. (1997), Encyclopedia of Phenomenology, London: Kluwer Academic Plubisher.

Hakim, Abdul. (1989), Jakarta Tempo Doeloe, Jakarta: Penerbit Antar Kota. Haryadi, B.Setiawan, 2010, Arsitektur Lingkungan dan Perilaku: Pengantar ke Teori, Metodologi dan Aplikasi, Yogyakarta: Gadjah Masa University Press.

Heuken, Adolf. (1997), Tempat-tempat Bersejarah di Jakarta, Jakarta: Penerbit Cipta Loka Caraka.

Heuken, Adolf. (2003), Mesjid-mesjid Tua di Jakarta, Jakarta: Penerbit Cipta Loka Caraka.

Jacobs, Melville. (1964), Pattern in Cultural Anthropology, Illinois: The Dorsey Press 